Preprint of Árvai M., Popa I., Mindrescu M, Nagy B., Kern Z. (2016) Dendrochronology and radiocarbon dating of subfossil conifer logs excavated from a peat bog, Maramures Mts, Romania. Quaternary International 415: 6-14., doi: 10.1016/j.quaint.2015.11.066

\title{
Dendrochronology and radiocarbon dating of subfossil conifer logs from a peat bog, Maramureș Mts, Romania
}

\author{
Mátyás Árvai ${ }^{1}$, Ionel Popa ${ }^{2}$, Marcel Mîndrescu ${ }^{3}$, Balázs Nagy ${ }^{1}$, Zoltán Kern ${ }^{4}$ \\ 1 Dept. of Physical Geography, Eötvös Loránd University, Budapest, Hungary, \\ matyas.arvai@gmail.com \\ ${ }^{2}$ National Research and Development Institute for Silviculture Marin Dracea, Câmpulung \\ Moldovenesc \\ ${ }^{3}$ University Suceava, Department of Geography, Cirques \& Lakes Research Group, Romania \\ ${ }^{4}$ Institute for Geology and Geochemistry, MTA Research Center for Astronomy and Earth \\ Sciences, Budaörsi út 45. 1112 Budapest, Hungary Hungary, kern@geochem.hu
}

\begin{abstract}
Fifty-six subfossil samples, dominantly Norway spruce (Picea abies (L.) Karst.), have been collected between 2010 and 2014 from a peat bog located on the Vinderel Plateau, Farcău Massif, Maramureș Mountains (Romania). Seven floating chronologies have been developed so far. The longest floating chronology contains 259 years while the shortest one spans 56 years. The oldest and youngest ages obtained from six of the radiocarbon dated samples are $1717 \pm 19 \mathrm{yr}{ }^{14} \mathrm{C}$ BP $(255-388 \mathrm{cal} \mathrm{AD})$ and $1039 \pm 16 \mathrm{yr}{ }^{14} \mathrm{C}$ BP $(985-1023 \mathrm{cal}$ AD), respectively.

The floating chronologies provide altogether an incomplete coverage over of the c. 200 to $1326 \mathrm{AD}$ period. These floating chronologies - supported with ${ }^{14} \mathrm{C}$ dates - provide a crucial step towards the production of an Eastern Carpathians composite coniferous chronology.

The lack of trunk accumulation after the early- $14^{\text {th }}$ century suggests the disappearance of trees from the proximity of the site. It closely follows the sharp increase of grazing indicator pollens in the region around the late- $13^{\text {th }}$ century. Conjunctly, this evidence points to a substantial landscape/land use change from forest to pasture during the $13^{\text {th }}$ century which probably indicates the beginning of the typical traditional vertical transhumance which became a characteristic livestock management in the Maramureș region over the past centuries.
\end{abstract}

Keywords: bog wood, Picea abies, Carpathians, peat bog, wiggle matching, subfossil

\section{Introduction}

The need for high-resolution accurately dated palaeoclimatological reconstruction has increased the importance of tree-ring investigations. Starting from the living trees dendrochronological methods can help to match tree-ring sequence from formerly fallen dead wood, historical timber, and subfossil trees (Cook and Kairiukstis, 1990; Speer, 2010). Owing to this sequential dating process, tree-ring records exceeding significantly the biological longevity of the studied species can be established. Such well dated long chronologies, have high importance in Holocene palaeoclimate studies (Briffa, 2000). 
Subfossil wood plays a crucial role in extending the dendrochronological timescale by centuries to millennium scale. They provided the dominant contribution to the longest treering chronologies in the polar region (Naurzbaev et al., 2002; Eronen et al., 2002).

Despite the fact that the longest European tree-ring chronologies from living trees have been established from stands growing at high altitude mountain sites relatively few studies reported subfossil samples from the same mountainous regions of Europe (Selsing, 1998; Nicolussi et al., 2009; Büntgen et al., 2011). However, high elevation subfossil bog and lake sites are expected to have similarly high potential to contribute to very long dendrochronological records, as is the case in the ecoclimatologically similar arctic and subarctic lowland environments. An excellent example in this respect are the Tyrolean Alps where a multispecies multimillennial conifer chronology has been achieved (Nicolussi et al., 2009) and upgraded recently to cover practically the entire Holocene (Nicolussi et al., 2014).

Interestingly, while subfossil wood is frequently found and processed to extend the dendrochronological timescales in the Eastern European lowlands (Krapiec, 2001; Kolár et al., 2012), similar findings were reported only sporadically in the mountainous region and no locality with a larger set of subfossil logs has been documented thus far from the Carpathian, or specifically East Carpathian domain.

This paper presents the first results of dendrochronological investigations from a peat bog site from the Northeastern Carpathians, situated in the vicinity of the Romanian-Ukrainian border, where dozens of spruce logs have been excavated between 2010 and 2014 .

\section{Materials and Methods}

\subsection{Site description and sample collection,}

The peat bog site with subfossil trunks was discovered in 2010. It is located on the Vinderel Plateau, Farcău Massif, Maramureș Mountains (Romania). Probably due to its very small size the bog has no specific name even in the local toponymy, so for the sake of simplicity we propose 'Vinderel 3' to differentiate it from the other two larger bogs of the Vinderel Plateau. The peat bog (1530 m a.s.1., N4754'11', E24²6’37’) lies below Rugașu ridge (c. $1820 \mathrm{~m}$ asl) and the locality serves as a conservation area for fallen down coniferous trees (Fig. 1). Peat deposits were formed in a landslide concavity ('slope pocket') on the western slope of Farcău Massif (Fig. 1). Nowadays the site is surrounded by a completely deforested landscape (Fig.2), and Farcău Massif lies above the depressed treeline. Based on cartographic evidence, such as the data provided by the Second Military Survey of the Hungarian Kingdom (from the 1860's) and the Forests of the Hungary (1885) the study site had been deforested for at least 150 years. Fieldwork was carried out between 2010 - when the conservation site was first explored - and 2014. Altogether 56 subfossil samples have been collected from the peat bog (Fig. 2). A shallow drilling survey at multiple holes over the basin revealed two main sedimentary units (Árvai et al., 2015). The deeper one, taking up approx. one third of the profile, is an organic rich lake deposit with abundant arboreal macrofossils (such as cones, bark, branches, and trunks). It is overlain by a peat blanket, taking up the remaining upper two-third of the profile, which consist dominantly of Sphagnum material and a small number of trunks. Most of the subfossil logs are found in the range of 0.5 meter depth, while the 
Preprint of Árvai M., Popa I., Mindrescu M, Nagy B., Kern Z. (2016) Dendrochronology and radiocarbon dating of subfossil conifer logs excavated from a peat bog, Maramures Mts, Romania. Quaternary International 415: 6-14., doi: 10.1016/j.quaint.2015.11.066

deepest trunks were found more than 1.5 meters deep, and just a few samples were on the surface.

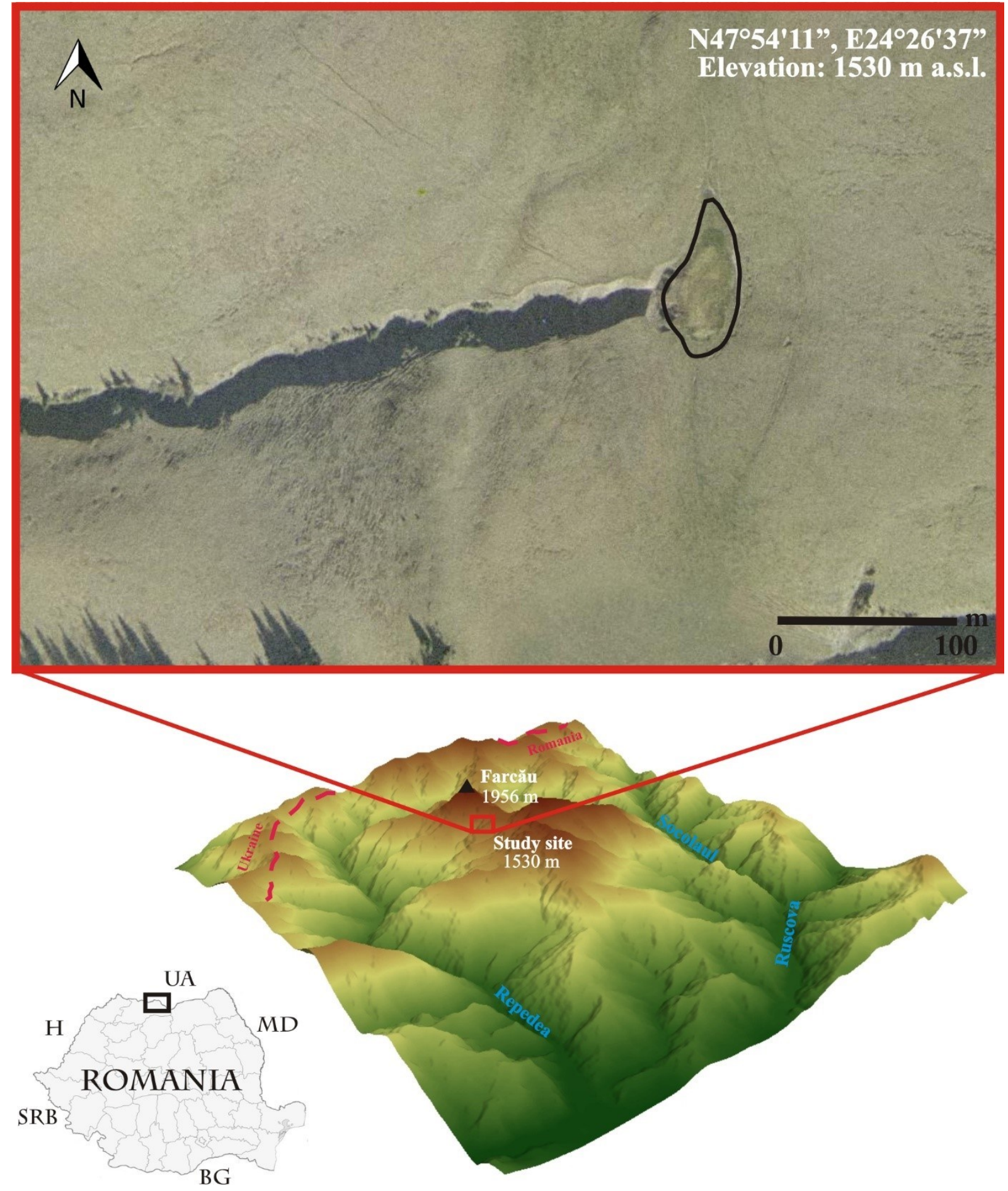

Figure 1. Location of the study site. The peat bog is outlined in the orthophoto (top). The location in the range is indicated on the digital terrain model, while black rectangle shows the Maramureș Mts at the Romanian Ukrainian border (inset map).

\subsection{Sampling, preparation and dendrochronological analysis}

Five to $10 \mathrm{~cm}$ thick disks were sawn from the unearthed logs. We sampled every single trunks only once. Sample surfaces were processed by machine operated abrasive belts with gradually 
finer grit size until tree-ring structure became clearly visible. The samples have been subjected to dendrochronological analysis. Tree-ring sequences were carefully checked and rings were counted. The minimum and maximum counted rings were 31 and 196, respectively (Fig. 3a). The majority of wood remains are Norway spruce, but very few are Silver fir (Abies alba Mill.) and one was undetermined. A LINTAB system and TSAP Win 4.68 software (Rinn, 2005) were used to measure the tree-ring widths with a precision of $0.01 \mathrm{~mm}$, as well as to crossdate the growth series by graphical comparison against each other (Cook and Kairiukstis, 1990; Popa, 2004; Speer, 2010). Two radii were measured on each disk. Measurement and crossdating were performed using the facilities of the Budapest Tree-Ring Laboratory (Eötvös University, Dept. of Palaeontology) (Kázmér and Grynaeus, 2003).

Two samples (MAR042 \& 043) with strikingly similar visual appearance collected at nearby excavation sites presented highly correlated ring-width patterns. Likely both ends of the same trunk were sampled in this case. Their measurement records were averaged and only the mean tree-ring width series was used in further dendrochronological synchronization. Two small diameter samples (MAR026, MAR027) were identified as branches. Their tree-ring width series were involved, without success, in the dendrochronological synchronization procedure but were left out of consideration when the age structure of the subfossil population was assessed (Fig. 3b). Seven samples (MAR031-035, and MAR037 \& 038) identified as Silver fir found at a relatively shallow depth belonged to some simple wooden construction with obvious marks of human processing (axe carving). These samples were also left out of consideration when the age structure of the subfossil population was assessed and will be discussed in a separate paper. Furthermore, a small diameter log (MAR036), found close to one element of the wooden construction, was also discarded because its wood differed from the typical Gymnosperm anatomical structure, although the species cannot be identified due to the relatively poor, heavily decayed, condition. Finally, the tree-ring width series of 44 individual trunks were entered into the dendrochronological synchronization stage of the research.

Standard dendrochronological statistics, such as the percentage of agreement (GLK: Gleichläufigkeit\%, Eckstein and Bauch, 1969) and the modified $t$ value ( $t_{\mathrm{BP}}$, Baillie and Pilcher, 1973) were used to evaluate crossdating results.

Whereas the majority of extracted disk samples contained the pith, it was missing in 20 samples. The number of missing rings to pith could be reliably estimated for 13 samples when only a small inner portion was missing. Pith offset estimation using graphics of concentric circles (Applequist, 1958) resulted in 1 up to 8 missing rings. Larger inner parts were missing from the rest of the samples, therefore a uniform pith offset (50) was assigned to these samples. This is obviously an arbitrary value which very likely underestimates the real number of missing rings in some cases; however, it helps to correct the distribution of the age structure of the subfossil population (Fig. 3b).

Moreover, so-called frost rings were also recorded in the subfossil samples. The frost ring is a characteristic anatomical marker of freezing temperatures sustained during the vegetation period (Glerum and Farrar, 1966). 
Figure 2. Close-up view of the peat bog with the main sedimentary units. The longest (A-A') and shortest (B-B') traverses are marked on the site view. Sedimentary units estimated by geospatial modelling based on shallow core stratigraphic data are displayed along the corresponding profiles. Positions of the excavated logs are projected to the closest section of these profiles to illustrate their relative stratigraphical relationship. Top-right site photo shows samples MAR012 and MAR010. While MAR012 is in the embedded position MAR010 has already been removed from the original position which was above MAR012. MAR009 originated from the same trench, just above MAR010. Bottom-right picture presents three sampled trunks in their original position whereby the samples had been synchronized in three different chronologies. Their relative stratigraphic order was: deepest MAR020, highest MAR017 while MAR018 was situated between them.

\subsection{Radiocarbon analysis}

Seven samples were selected for radiocarbon analysis. Samples were pretreated by the conventional acid-alkali-acid (AAA) treatment. Measured targets were prepared using a sealed-tube graphitization method (Molnár et al., 2013a; Rinyu et al., 2013). The ${ }^{14} \mathrm{C} /{ }^{12} \mathrm{C}$ ratio and its ${ }^{13} \mathrm{C} /{ }^{12} \mathrm{C}$ correction were measured by accelerator mass spectrometry (AMS) on the EnvironMICADAS ${ }^{14} \mathrm{C}$ facility in the Hertelendi Laboratory of Environmental Studies in Debrecen, Hungary (Molnár et al., 2013b). The radiocarbon ages were calculated according to Stuiver and Polach (1977). Calibration of ${ }^{14} \mathrm{C}$ dates to calendar years was performed by the 
OxCal v.4.2 (Bronk Ramsey, 2009) program in conjunction with the Northern Hemisphere IntCal13 (Reimer et al., 2013) dataset.

When multiple ${ }^{14} \mathrm{C}$ samples were available from dendrochronologically synchronized series, the -so-called wiggle-matching technique (Bronk Ramsey et al., 2001) was employed for calibration of radiocarbon results using the D_Sequence function from the OxCal v.4.2 (Bronk Ramsey, 2009) program. This means that owing to the precise a priori knowledge, provided by the dendrochronological synchronization, i.e. the exact number of annual rings between the blocks of rings subjected to radiocarbon measurements, the radiocarbon counting errors are minimized, thus allowing for dating with considerably higher accuracy than in case of single radiocarbon measurements (Pearson, 1986; Bolka and Krąpiec, 2012).

\section{Results}

\subsection{Synchronization of tree-ring width chronologies}

The findings for the dendrochronological assessment of subfossil conifer bogwoods in the Maramureș Mts are based on the analysis of 44 trunk samples. Measured ring counts showed a trimodal distribution (Fig. 3a) which became even more expressed in the age distribution histogram (Fig. 3b) when pith offset estimates were taken into consideration. Less than 60 measurable rings were found in one third $(n=15)$ of the sample set. Eleven samples contained more than 150 measurable rings. These relatively longer records were invaluable during the dendrochronological synchronization.

Thirty-two samples were grouped into four clusters (Figure S1, S2 in the Supplementary Material). The longest covered period is 259 year for MM1 enclosing 9 samples. The second longest floating chronology (188 years) is MM2 which is the most replicated group containing 10 samples. MM3 covers 166 years represented by 5 samples while the 6 series grouped in MM4 span 141 years. In addition, three doublets (synchronized pairs) were also developed (Figure S3). The MAR017-024 covers 166 years, MAR029-053 spans 56 years while the shortest record is provided by the MAR007-012 doublet counting only 47 years. There were 11 samples ( 9 trunks and 2 branches) whose tree-ring width series had not produced any acceptable synchronous pattern with any other sample from the dataset. 

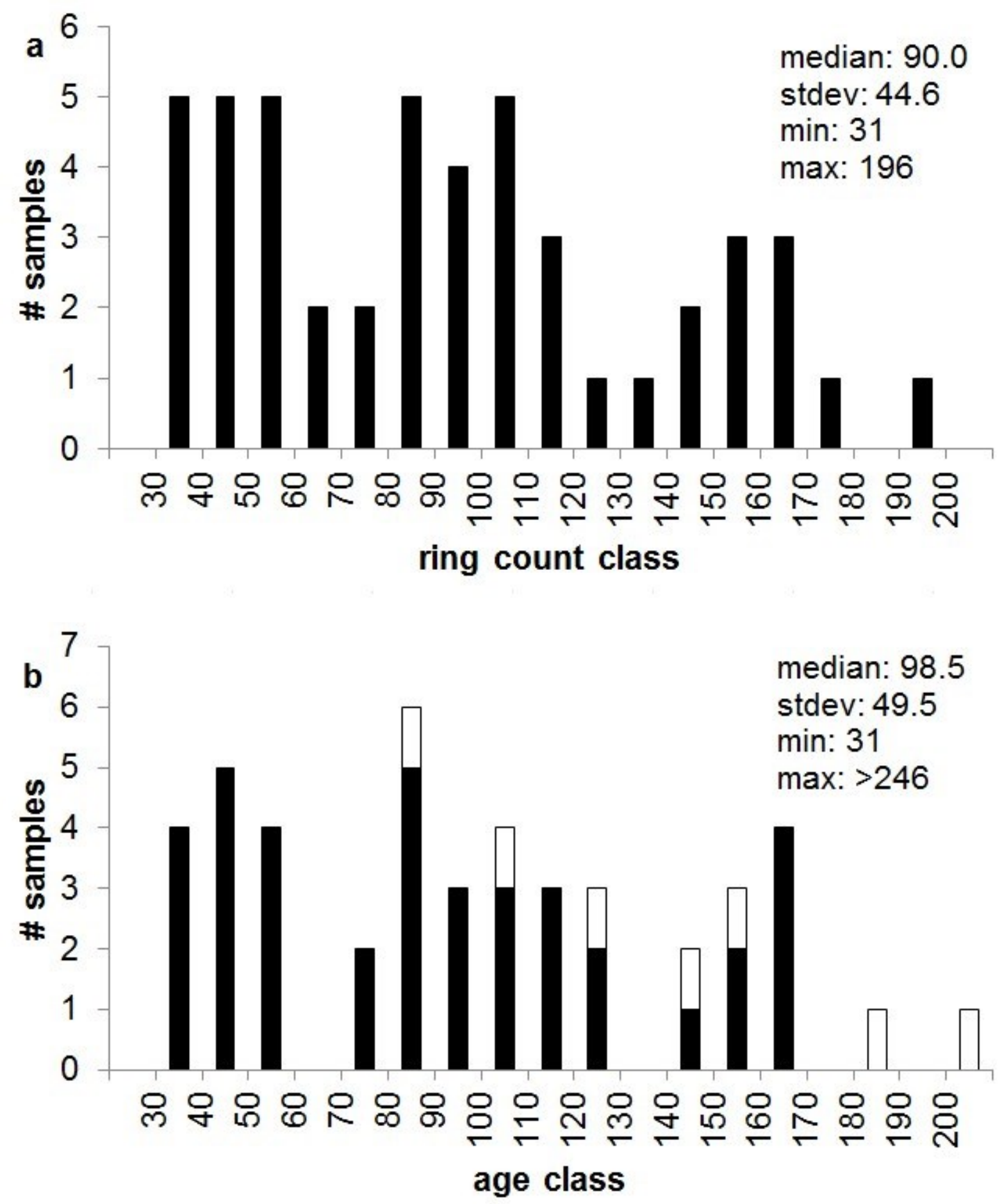

Figure 3. Age distribution of the analysed samples. a: Ten-years clusters according to the counted number of rings. b: Estimated age of the samples obtained after correction for pith offset and non-measurable rings are shown in similar ten-years clusters. Samples where the pith offset was estimated uniformly at 50 due to larger missing inner part are indicated as white boxes. Basic statistics are shown in the top right corner. 
Table 1. Sample description with conventional and calibrated ages of wood samples taken from dendrochronologicaly crossdated subfossil oak samples. Unmodelled age ranges show the simple calibration, while modelled ones are wiggle-matching estimates (where applicable). When unmodelled $2 \sigma$ range split up corresponding portion of percentage is given in brackets after the end date of the interval.

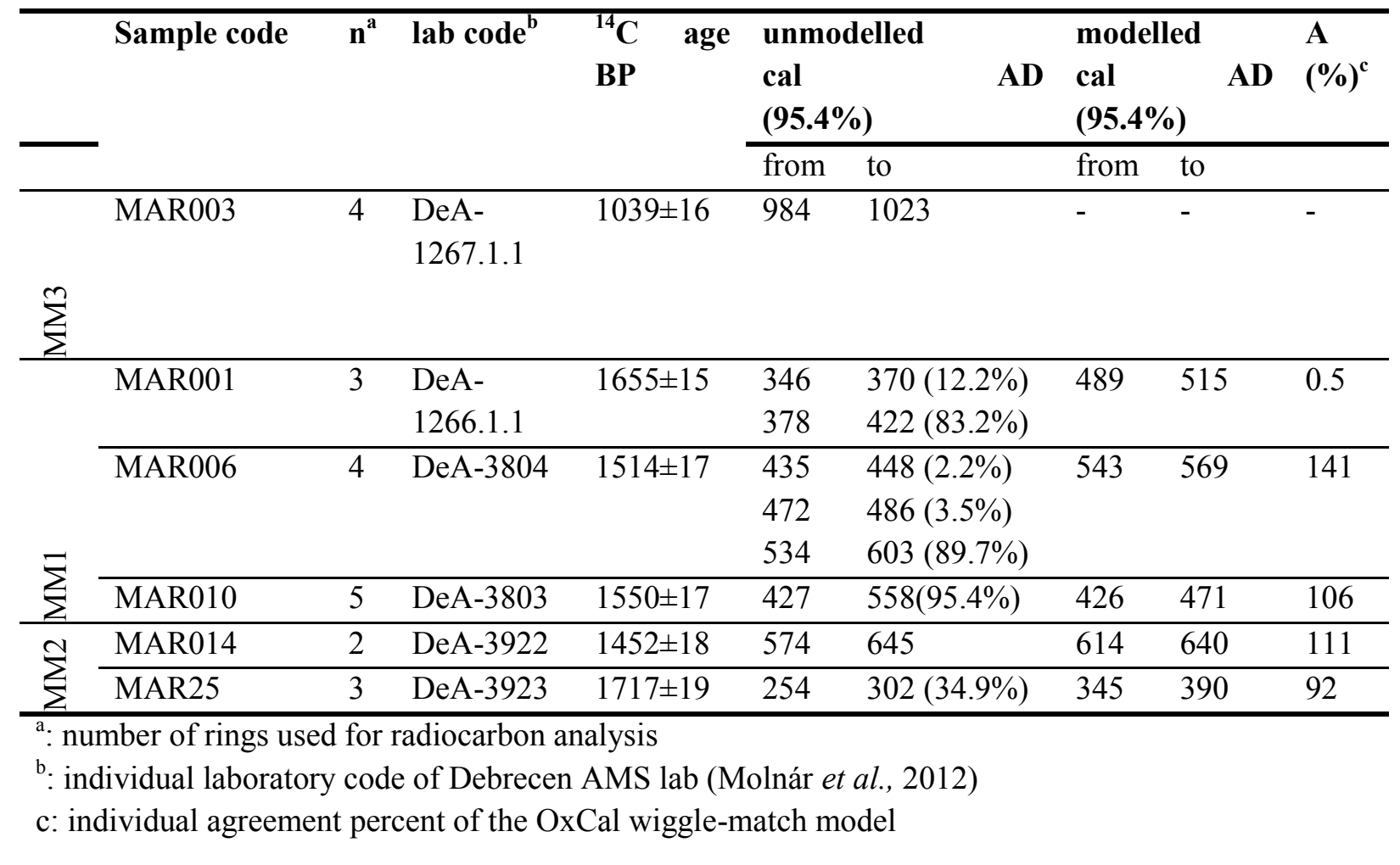

\subsection{Radiocarbon results}

The single sample subjected to radiocarbon dating from the MM3 chronology yielded the youngest age among the analysed samples (Tab. 1). Two samples were dated from the MM1 cohort with an estimated gap of 81 years. Finally, three samples were analysed from the MM2 chronology and the gap between them counted based on their dendrochronologically determined relative age were 54 and 71 years, respectively.

The wiggle-matching procedure remarkably constrained the single-sample calibrated ranges (Tab. 1). The Bayesian wiggle-match of radiocarbon ages of MM1 (Fig. S4) and MM2 (Fig. S5) gave a felling date to the terminal ring 537-582 cal AD and 626-652 cal AD, respectively. The OxCal agreement index proved to be satisfactory in all but one (MAR001) case. In such situations, such a date is usually excluded from the procedure wiggle-matching. We tested the wiggle-match dating without the MAR001, however there was no significant change. The upper and lower margins of the $95.4 \%$ uncertainty range broadened by $\sim 4$ years without any major shift. Therefore we used the wiggle-match results from the all the three samples. The extracted rings from this sample represented a juvenile section $\left(\sim 25-27^{\text {th }}\right.$ year of the life of the MAR001 tree), which might be related to the older than expected age. 

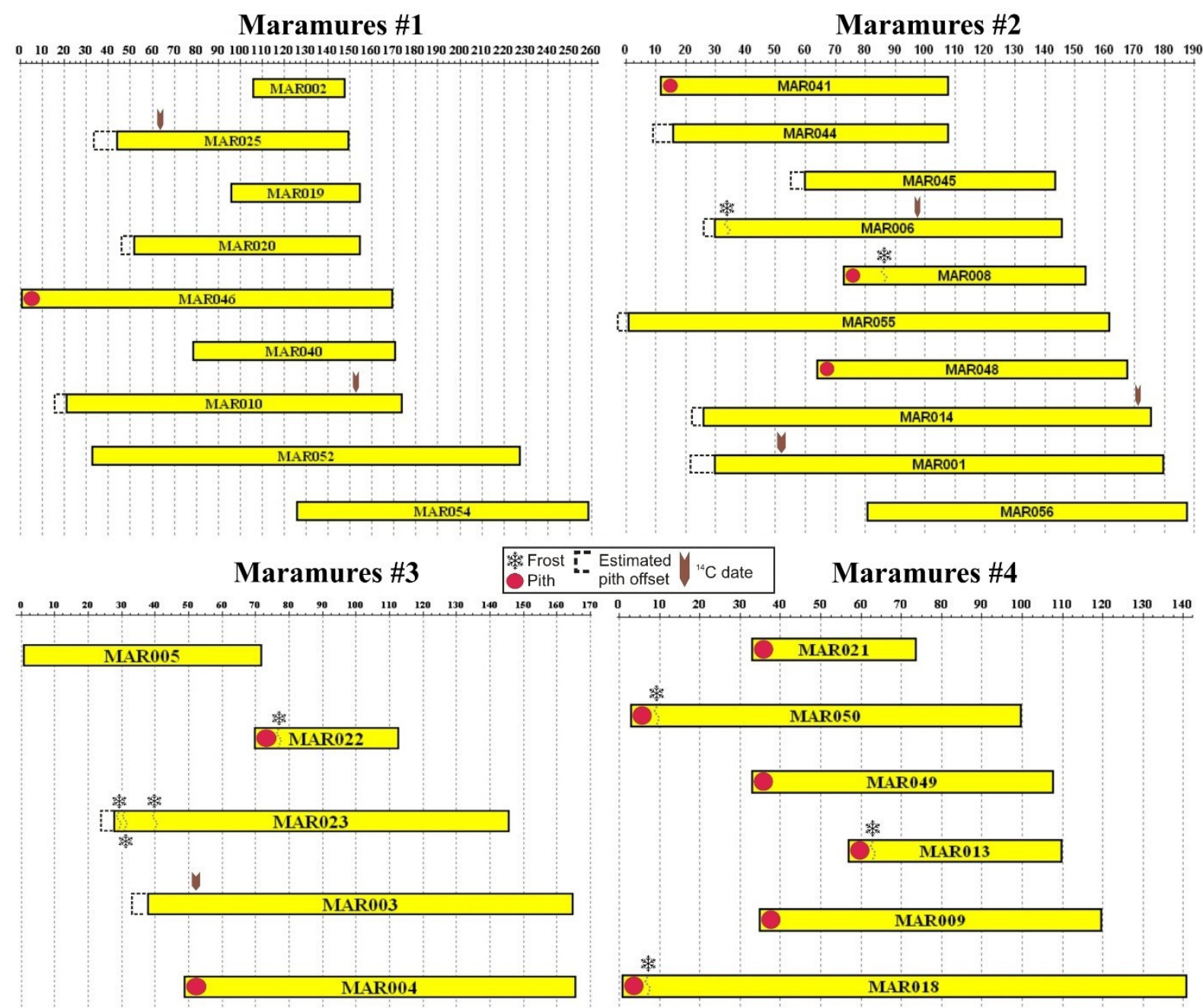

Maramures \#2

Estimated
pith offset ${ }^{14} \mathrm{C}$ date $\quad$ Maramures \#4

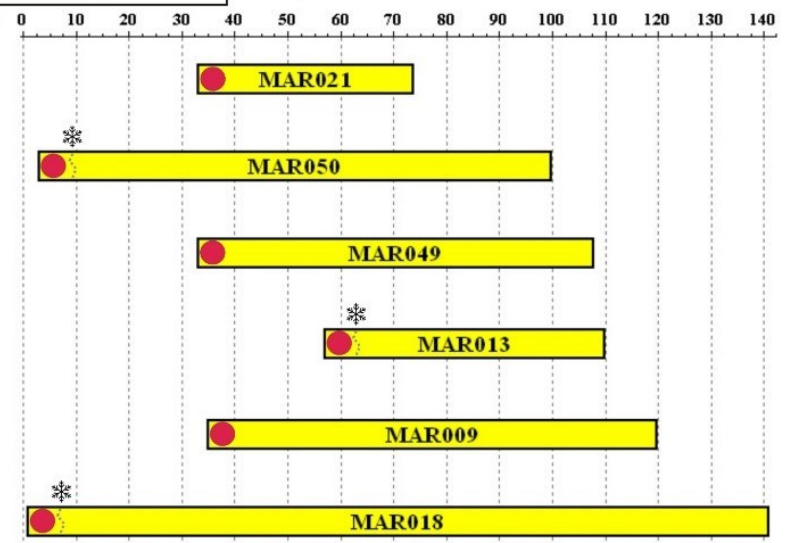

Figure 4. Gridbeam charts of the established floating chronologies. Observed pith is indicated by full dot. Reliable pith offset estimate is shown as dashed extension at the young end (i.e. left side) of the corresponding beam. Large missing inner part hampered accurate reliable pith offset estimation for the rests. Snowflake symbol marks frost injury. Arrows point to radiocarbon dated sections.

\subsection{Fix dates after crossdating with local master chronologies}

The longest spruce chronologies with fixed calendar dates (so called master chronologies) are available from $1698 \mathrm{AD}$ (Charnagora Mts, $30 \mathrm{~km} \mathrm{~N}$, Kaczka and Büntgen, 2007) and from 1588 AD (Calimani Mts $100 \mathrm{~km}$ SE, Popa and Sidor, 2010) in the region.

Since most of the chronologies constrained by ${ }^{14} \mathrm{C}$ data or stratigraphical information are older than the beginning of these chronologies only the MAR029-053 doublet and the single series without match among the subfossil samples were entered in a crossdating test against these master chronologies. However, the crossdating trials showed no meaningful result.

As known for many other mountain regions worldwide, in the Carpathians it was also shown that summer temperature conditions are the primary regulator of radial growth of conifers with increasing altitude (Savva et al., 2006; Büntgen et al., 2007). Evidently, this factor forces spreading of the strong common signal over an extended area with increasing altitude as observed in the neighbouring Rodna Mts (Timis and Popa, 2010). A recent regional 
investigation clearly pointed out that above $1300 \mathrm{~m}$ a.s.1. the summer temperature is the main growth modulator of Norway Spruce in the Eastern Carpathians (Sidor at al., 2015) and similar conclusion was drawn to provide an independent verification by another recent study (Primicia et al., 2015). Therefore it was reasonable to involve a much longer summer temperature sensitive Stone Pine chronology (Popa and Kern, 2009) into the crossdating procedure. This is especially suited, since the ring counts from the ${ }^{14} \mathrm{C}$ dated section (Tab. 1) until the terminal ring of MM3 (103) gave an estimated range of 1087-1126 AD which is well within the covered period of the Calimani pine chronology. The MAR029-053 doublet, which is expected to be even younger than MM3 is also a promising candidate in this crossdating test. Nevertheless, at the study site important tree growing factor can be the water table level fluctuations of the peat bog (Edvardsson et al., 2012, Edvardsson and Hansson, 2015). Most of the samples have grown at the edge of the bog, so the water level change might influenced unique growing patterns.

Although the crossdating statistics are not very high the result could provide fix calendar date for the MAR029-053 doublet (Fig. 5). However, only weak crossdating results were obtained for the MM3 floating chronology. Obviously, the short overlap with relatively poorly replicated early part of the Calimani pine chronology can be an explanation. In addition, probably the samples of MM3 grew at the edge of the peat bog, so water level fluctuations episodically might also influence tree growth, disturbing the temperature signal. The ringwidth pattern defined by the MAR029-053 doublet has been synchronized to the wellreplicated portion of this pine master chronology. In brief, the Calimani pine chronology could help to assign fix calendar date to one established subfossil spruce chronology. The first/last rings in the MAR029-053 doublet is supposedly 1271/1326 AD.

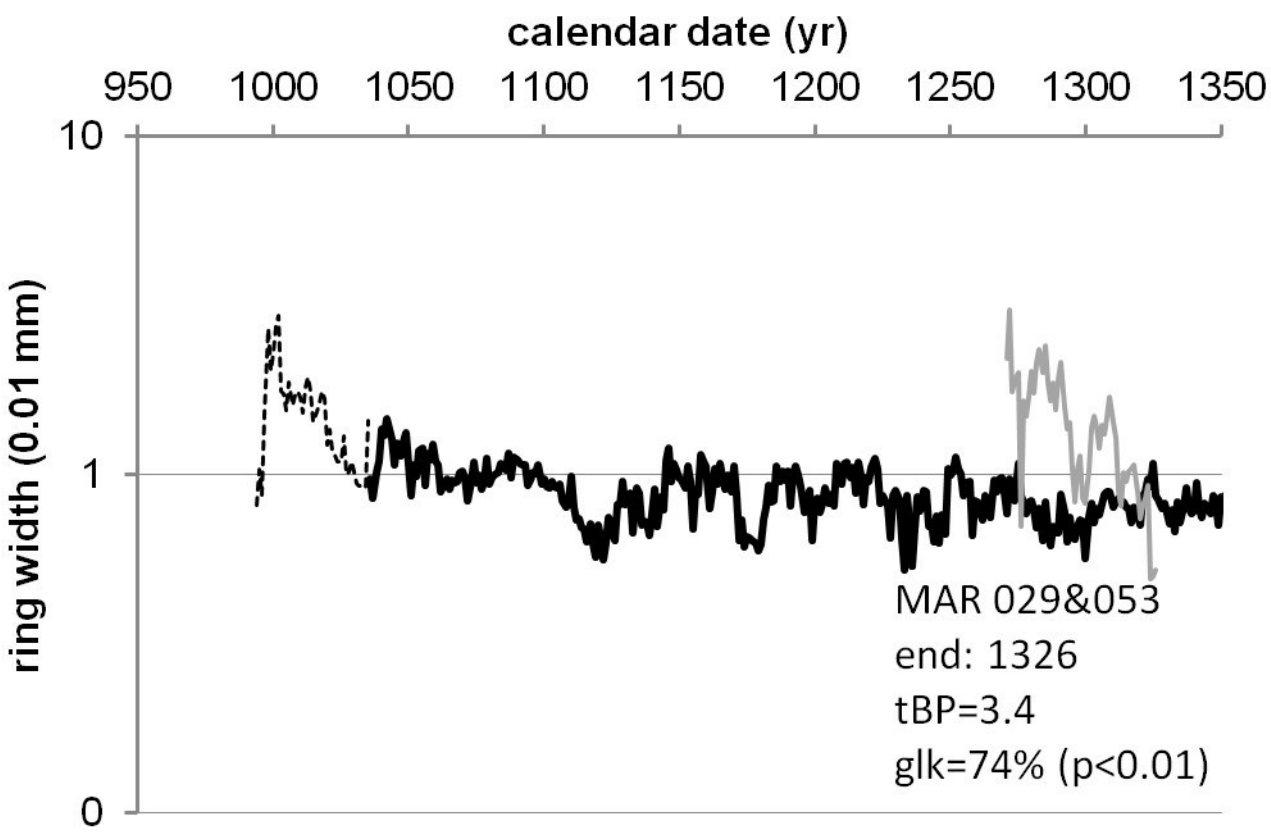

Figure 5. Dendrochronological dating of the MAR029\&053. The Calimani pine chronology (black, Popa and Kern 2009) and the youngest peat bog derived subfossil spruce chronology (grey) plotted in its synchronized position. End date and crossdating statistics are displayed below the corresponding curve. Poorly replicated ( $<5$ trees) earliest section of the pine master chronology is displayed by dashed line but was disregarded in the crossdating test. 


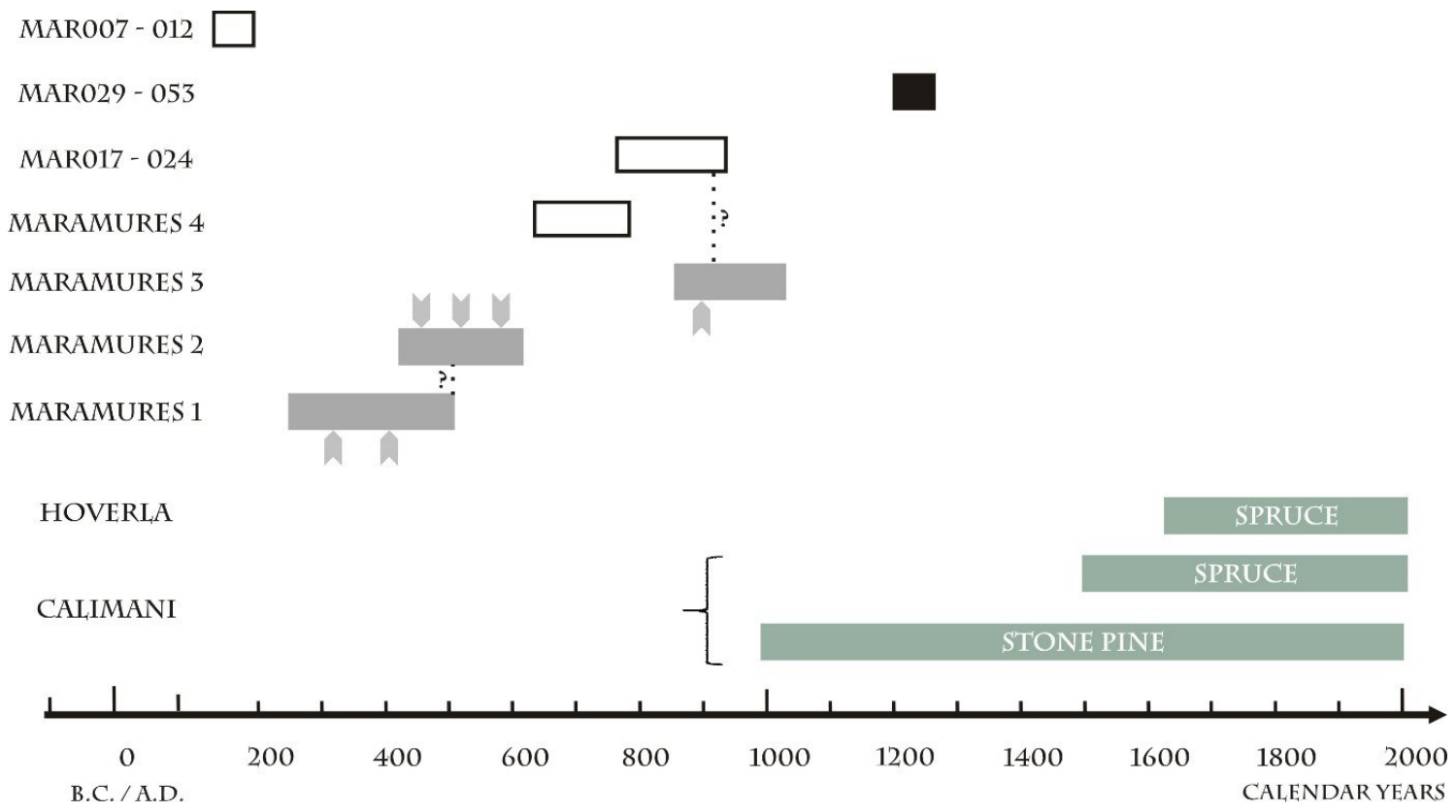

Figure 6. Approximate temporal coverage of the established floating spruce chronologies and three synchronized doublets. Black stripes mark the dendrochronologically dated chronology. Floating chronologies with radiocarbon age constraints are shown as dark grey stripes. Arrows pinpoint to the radiocarbon dated sections. The relative positions of the additional fragments (white stripes) are proposed with respect to the stratigraphical relationships. Dashed vertical lines with question marks indicate assumed links. Time span of the longest nearby master chronologies (Hoverla c. $30 \mathrm{~km} \mathrm{~N}$, Kaczka and Büntgen, 2007, Calimani c. 100 km SE, Norway Spuce: Popa and Sidor, 2010; Stone Pine: Popa and Kern, 2009) available from the region are also shown.

\section{Discussion}

\subsection{Relative sequence of the samples}

Radiocarbon dates and certain stratigraphical relationships observed between unearthed trunks helped to arrange a relative sequence of the floating chronologies (Fig. 6). The oldest dendrochronological sequences (MM1) for subfossil conifer trunks from the Maramureș Mts reach the end of the $2^{\text {nd }}$ century. The MM2 floating chronology covers almost 200 years and it has a common section with the end of the MM1, but the weak crossdating statistics were not encouraging enough to join them. We assume that only a relatively short section of the two chronologies might overlap which still challenges any successful dendrochronological synchronization. The third floating chronology supported by ${ }^{14} \mathrm{C}$ date (MM3) is c. 300 years younger than the terminating ring of the MM2 chronology. Although the MM4 chronology lacked any radiometric age constraint the stratigraphical observations (i.e. MAR018 was situated deeper than MAR017 (see Fig. 2)) helped to determine a relative position of the floating chronology on the timescale. The MAR029-053 doublet was assigned the youngest age on the timeline according to their stratigraphical locations supported by the crossdating results (Fig. 5). Furthermore, a crossdated doublet (MAR007-012) could be placed in a relatively older position on the timescale compared to MM1 based on the deeper 
stratigraphical location of MAR012 relative to MAR010 (Fig. 2), and the latter sample is enclosed in the MM1 cohort. We would like to note that additional stratigraphical relations are also in agreement with the proposed relative sequence, for instance MAR009 found above MAR010 and MAR12 has been placed in a younger cohort than both mentioned samples. Similarly, MAR20 found beneath MAR017 and MAR018 has been placed to an older group than both of the above lying samples. Finally, MAR007-012 have been proposed as the oldest samples, while the youngest ones are in the MAR029-053 doublet (Fig. 6).

It is interesting to note the characteristic differences in pith condition among the sample sets of the four chronologies (Fig. 4). While pith was usually present in the samples of the younger cohorts (all samples contained pith in MM4, 2 out of the 5 samples contained pith in MM3) just one sample preserved the pith in the oldest cohort, where 5 out of the 7 samples were missing the inner part to a large extent. This pattern is in agreement with the assigned relative age of the cohorts and provides a method of indirect verification, as it indicates that the innermost part was well preserved in younger samples and more damaged in older samples.

\subsection{Frost ring occurrence in the subfossil samples}

After c. 4500 rings were checked in the subfossil material 27 frost rings were detected. All the frost rings were observed in the earlywood indicating late-spring/early summer frost events. Frost rings have been observed in recent spruce wood (Panayotov et al., 2011, Biczyk and Kaczka, 2014) and even other conifers (Popa et al., 2006, Panayotov and Yurukov, 2007, Kern and Popa, 2008) in the region. Although the replication of this subfossil dataset is severely limited some particularities can be compared to modern records.

We could not observe any frost injuries in rings older than 15 yrs of the tree-life. This indicates that only juvenile rings have been affected in a similar manner to recent observations (Panayotov et al., 2011, Biczyk and Kaczka, 2014). In addition, no temporally aligned frost rings affecting coincidently several individuals were observed (Fig. 4), which suggests that these frost rings do not document any large devastating frost event (Popa et al., 2006) but more likely the anatomical markers document the 'usual' late spring cold spells.

A relative concentration of frost ring occurrence can be seen in MM3 between 30 and 80 years (estimated calendar date is in the $10^{\text {th }}$ century) when 4 out of the 27 detected frost rings were found. This might be a historical period when late spring frost occurred at a relatively greater frequency.

\subsection{Implications for historical landscape changes}

\subsubsection{On the possible date of the mass movement creating the lake/peat bog basin}

It was expected that a characteristic mass mortality event of the subfossil trees will indicate the date of the mass movement creating the basin. However, the currently available samples have not defined such an initial mass mortality event. The first modest mortality peak with three closely matching felling dates is seen in MM1, at the $155^{\text {th }}$ years of the chronology (Fig. 4). Although we argue that this event is more likely linked to deforestation rather than a geomorphological event (see section 4.3.2.) the estimated age of the felling date of these trees (433-478 AD) suggests that the lake basin had already existed before the late- $5^{\text {th }}$ century. It is assumed that either the MAR007-012 doublet, or one of the non-dated 11 samples might 
represents the earliest remains from the basin, so this first estimation can be better constrained in the future.

\subsubsection{Establishment of the current artificial meadows at the proximity of the study site}

As noted above the first modest mortality peak in MM1 is seen at the $155^{\text {th }}$ years of the chronology. MAR019 and MAR020, both with preserved waney egde, have been synchronized to exactly the same felling date (Fig. 4) while the terminal ring of MAR025 is dated 5 years earlier but the outer edge of this sample has been slightly eroded and few rings were lost during preparation. Therefore, these three samples are thought to indicate a coinciding mortality event at an estimated age between 433 and 478 AD. The next three samples (MAR046, MAR040, and MAR010) also show closely matching felling dates, less than 20 years following the first event.

The mid- $5^{\text {th }}$ century was one of the largest deforestation periods in Maramureș Mts as indicated by the arboreal/non-boreal ratio documented in the pollen spectra at a nearby site (Farcaş et al. 2009, Farcaş et al., 2013). Important to note that the steep decline in arboreal pollens was primarily driven by the reduction of spruce, and less markedly of fir, which showed a less severe drop in abundance. Therefore, this forest decline has been pinpointed to the subalpine conifer belt and the observed felling phases determined in the subfossil spruce population of this peat bog are in good agreement with the decline of the spruce forest suggested by the microbotanical evidence found at nearby sites. This deforestation was regarded as a form of early human impact in NE Romania (Farcas et al., 2013) and ensued by the occurrence of Urtica in the regional vegetation (Farcaş et al., 2013) which is a significant grazing indicator (Behre, 1981, Gaillard et al., 1992). Thus, this period represents the initial stage of the anthropogenic deforestation of the coniferous belt and likely coincides with an early period of the high mountain grazing activity in Maramureș.

Recently published sedimentary records from the subalpine zone of the northern Romanian Carpathians reported increased paleofire activity and associated rise in primary (cultivated) and secondary anthropogenic indicators (pastoral) suggesting anthropogenically-induced fires around this period. High fire activity was reported from the southern side of the nearby Rodna Mts (Tăul Muced) between 1,300 and 1,100 cal yr BP (Feurdean et al., 2015) while a period of higher macro-charcoal concentrations was fund between 1,500 cal yr. BP and 1,000 cal yr BP at northern (Lake Stiol, Lake Buhaescu Mare) side of the Rodna Mts (Haliuc et al., 2016). Further on, the palynological record suggests that regeneration following this drastic decline lasted until the beginning of the $11^{\text {th }}$ century (Farcaş et al. 2009, Farcaş et al. 2013).

The lack of subfossil samples dated after $1326 \mathrm{AD}$ is indirect evidence of the forest-line departure from the peat bog's altitude by that time. This date aligns fairly well with the exponential increase of Urtica in the regional pollen spectra (Farcaş et al., 2013) indicating further increase of grazing activity. Another accurately dated, high resolution palynological record from a similar high-elevation site (Taul Muced, Rodna Mts) showed increased human indicators in the upland herbs (e.g. Urtica, Plantago) between 1100 and 1250 AD (Feurdean et al., 2015). The broad coincidence of the disappearance of tree macrofossils and intensification of grazing indicators in the regional pollen spectra (Farcas et al. 2013, Feurdean et al., 2015) could indicate that the turn of $13 \mathrm{rd}$ and $14^{\text {th }}$ centuries is likely the 
approximate beginning of the current transhumance activity in the high mountains of Maramureș region. Consequently, this means that the current artificially depressed treeline and the resulting treeless subalpine landscape has at least a c. 700 year old history in the Maramureş region.

\section{Conclusions}

We have built four floating chronologies, of which three were anchored to the timescale based on radiocarbon dates. Altogether these chronologies provide a gappy coverage of an approximately eleven hundred years-long period, spanning from c. 200 to 1326 AD. The main implication based on the recorded frost rings is that this subfossil spruce population could be exposed to similar late spring/early summer frost conditions like the present spruce stands of the Carpathians. Felling and recruitment phases indicated by the pith offset corrected life spans of the trees largely corresponds with the regional vegetation history reconstructed based on microbotanical evidence (Farcaş et al. 2013). The successful crossdating between the temperature sensitive pine master chronology and one of the studied subfossil spruce chronology lived near the former thermal timberline produced a promising results regarding the future development of an Eastern Carpathian composite conifer chronology.

\section{Acknowledgements}

Thanks for support from "Lendület" program of the Hungarian Academy of Sciences (LP2012-27/2012) and a Romanian-Hungarian bilateral cooperation (RO-2013-0014). This is contribution No.32. of 2ka Palæoclimatology Research Group and No.27. of Budapest Tree-Ring Laboratory.

\section{References}

Applequist, M. B., 1958. A simple pith locator for using with off-center increment cores. J. For, 56-141.

Árvai M., Kern Z, Kohán B., Mîndrescu, M., Nagy B., 2015. A Farcău-tőzegláp medrének modellezése és térinformatikai elemzése fúrásadatok alapján. In: Boda J. (Ed.), Az elmélet és gyakorlat találkozása a térinformatikában VI., Debrecen University Press, Debrecen, pp. 31-38. (in Hungarian with English summary)

Baillie, M. G. L., Pilcher, J. R., 1973. A simple cross-dating programme for tree-ring research. Tree-Ring Bulletin 33, 7-14.

Behre, K.-E., 1981. The interpretation of anthropogenic indicators in pollen diagrams. Pollen et Spores 23(2), 225-245.

Biczyk T., Kaczka R.J. 2014. Climatic conditions causing formation of wood anomalies of Norway spruce (Picea abies L. Karst.) in the Tatras. Studia i Materiały CEPL, Rogów 40 (3), 9-18. (in Polish with English abstract)

Bolka, M., Krąpiec, M., 2012. Dendrochronological and radiocarbon dating of the medieval stronghold in Ujście (Poland). Geochronometria 39, 30-39, doi: 10.2478/s13386-0110057-y

Briffa, K. R. 2000. Annual climate variability in the Holocene: Interpreting the message of ancient trees. Quaternary Science Reviews 19, 87-105. 
Preprint of Árvai M., Popa I., Mindrescu M, Nagy B., Kern Z. (2016) Dendrochronology and radiocarbon dating of subfossil conifer logs excavated from a peat bog, Maramures Mts, Romania. Quaternary International 415: 6-14., doi: 10.1016/j.quaint.2015.11.066

Bronk Ramsey, C., 2009. Bayesian analysis of radiocarbon dates. Radiocarbon 51(1), 337360.

Bronk Ramsey, C, van der Plicht, J., Weninger, B., 2001. "Wiggle-matching" radiocarbon dates. Radiocarbon 43(2A), 381-89.

Büntgen, U., Frank, D. C., Kaczka, R. J., Verstege, A., Zwijacz-Kozica, T., Esper, J., 2007. Growth responses to climate in a multi-species tree-ring network in the Western Carpathian Tatra Mountains, Poland and Slovakia. Tree Physiology 27, 689-702.

Büntgen, U., Tegel, W., Nicolussi, K., McCormick, M., Frank, D., Trouet, V., Kaplan, O. J., Herzig, F., Heussner, K-U., Wanner, H., Luterbacher, J., Esper, J., 2011. 2500 Years of European Climate Variability and Human Susceptibility. Science 331, 578-582.

Cook, E., Kairiukstis, L. (Eds.), 1990. Methods of Dendrochronology. Applications in the Environmental Sciences Kluwer Academic Pub.

Eckstein, D., Bauch, J., 1969. Beitrag zur Rationalisierung eines dendrochronologischen Verfahrens und zur Analyse seiner Aussagesicherheit. Forstwissenschaftliches Centralblatt 88(4), 230-250.

Edvardsson J., Linderson, H., Rundgren, M., Hammarlund, D., 2012. Holocene peatland development and hydrological variability inferred from bog-pine dendrochronology and peat stratigraphy - A case study from Southern Sweden. Journal of Quaternary Science 27(6), 553-563.

Edvardsson, J., Hansson, A. 2015. Multiannual hydrological responses in Scots pine radial growth within raised bogs in southern Sweden. Silva Fennica vol. 49 no. 4 http://dx.doi.org/10.14214/sf.1354

Eronen, M., Zetterberg, P., Briffa, K. R., Lindholm, M., Meriläinen, J., Timonen, M., 2002. The supra-long Scots pine tree-ring record for Finnish Lapland: Part 1, chronology construction and initial inferences. The Holocene 12(6), 673-680.

Farcaş, S., Tantau, I., Mîndrescu, M., Hurdu, B., Filipas, L., Ursu, T. 2009. Pollen analysis of the sequence from the peat bog Taul Mare - Bardau (Maramuresului Mountains), Trans. Rev. of Syst. and Ecol. Res., Sibiu, 5, pp. 21-30.

Farcaş, S., Tantau, I., Mîndrescu, M., Hurdu, B., 2013. Holocene vegetation history in the Maramures Mountains (Northern Romanian Carpathians). Quarternary International 293, 92-104.

Feurdean, A., Galka, M., Kuske, E., Tantau, I., Lamentowicz, M., Florescu, G., Liakka, J, Hutchinson, S.M, Mulch, A., Hickler, T. 2015. Last Millennium hydro-climate variability in Central-Eastern Europe (Northern Carpathians, Romania). The Holocene 25, 1179-1192.

Gaillard, M-J., Birks, H. J. B., Emanuelsson, U., Berglund, B. E., 1992. Modern pollen/landuse relationships as an aid in the reconstruction of past land-uses and cultural landscapes: an example from south Sweden. Vegetation History and Archaeobotany 1, 3-17.

Glerum, C., Farrar, J. L., 1966. Frost ring formation in the stems of some coniferous species. Can. J. Bot. 44, 879-886. 
Haliuc, A., Hutchinson, S. M., Florescu, G., Feurdean, A. 2016. The role of fire in landscape dynamics: An example of two sediment records from the Rodna Mountains, northern Romanian Carpathians. CATENA, 137, 432-440.

Kaczka, R., Büntgen, U., 2007. Spatial autocorrelation and growth/climate response of a high elevation spruce network along the Carpathian arc. TRACE - Tree Rings in Archaeology, Climatology and Ecology 5, GFZ German Research Centre for Geosciences, Potsdam, pp. 103-112.

Kázmér, M., Grynaeus, A., 2003. The Budapest Tree-Ring Laboratory. Association for TreeRing Research Newsletter 1, 5-6.

Kern, Z., Popa, I. 2008. Changes of frost damage and treeline advance for Swiss stone pine in the Calimani Mts. (Eastern Carpathians, Romania). Acta Silvatica \& Lignaria Hungarica 4, 39-48.

Kolář, T., Kyncl, T., Rybníček, M., 2012. Oak chronology development in the Czech Republic and its teleconnection on a European scale. Dendrochronologia 30, 243-248.

Krąpiec, M., 2001. Holocene dendrochronological standards for subfossil oaks from the area of Southern Poland. Studia Quaternaria 18, 47-63.

Molnár M., Rinyu L., Janovics R., Major I., Veres M., 2012. Az új debreceni C-14 laboratórium bemutatása (Introduction of the new AMS C-14 laboratory in Debrecen). Archeometriai Mühely 9, 147-160. (in Hungarian)

Molnár M., Janovics R., Major I., Orsovszki J., Gönczi R., Veres M., Leonard, A. G., Castle, S. M., Lange, T. E., Wacker, L., Hajdas, I., Jull, A. J. T., 2013a. Status report of the new AMS C-14 sample preparation lab of the Hertelendi Laboratory of Environmental Studies, Debrecen, Hungary. Radiocarbon 55, 665-676.

Molnár M., Rinyu L., Veres M., Seiler, M., Winacker, L., Synal, H.-A., 2013b. EnvironMICADAS: a mini 14C-AMS with enhanced gas ion source interface in the Hertelendi Laboratory of Environmental Studies (HEKAL), Hungary. Radiocarbon 55, 338-344., doi: 10.2458/azu_js_rc.55.16331

Naurzbaev, M. M., Vaganov, E. A., Sidorova, O. V., Schweingruber, F. H., 2002. Summer temperatures in eastern Taimyr inferred from a 2427-year late-Holocene tree-ring chronology and earlier floating series. The Holocene 12, 727-736.

Nicolussi, K., Kaufmann, M., Melvin, T. M., van der Plicht, J., Schießling, P., Thurner, A., 2009. A 9111 year long conifer tree-ring chronology for the European Alps: a base for environmental and climatic investigations. The Holocene 19/6, 909-920.

Nicolussi, K., Weber, G., Patzel, G., Thurner, A., 2014. A question of time: extension of the Eastern Alpine Conifer Chronology back to 10071 b2k. TRACE - Tree Rings in Archaeology, Climatology and Ecology 13, GFZ German Research Centre for Geosciences, Potsdam, pp. 69-73.

Panayotov, M. P., Yurukov, I. S., 2007. Tree ring chronology of Pinus peuce from the Pirin Mts and the possibilities to use it for climate analysis. Phytologia Balcanica, 13 (3), 313-320.

Panayotov, M., Dimitrov, D., Yurukov, S., 2011. Extreme climate conditions in Bulgariaevidence from Picea abies tree-rings. Silva Balcanica 12(1), 37-46. 

radiocarbon dating of subfossil conifer logs excavated from a peat bog, Maramures Mts, Romania. Quaternary International 415: 6-14., doi: 10.1016/j.quaint.2015.11.066

Pearson, G. W., 1986. Precise calendrical dating of know growth-period samples using a "curve fitting" technique. Radiocarbon 28, 292-299.

Popa, I., 2004. Fundamente metodologice şi aplicaţii de dendrocronologie. Editura Tehnică silvică, Staţiunea Experimentală de Cultura Molidului, Câmpulung Moldovenesc, (in Romanian)

Popa, I., Kern Z., 2009. Long-term summer temperature reconstruction inferred from tree-ring records from the Eastern Carpathians. Climate Dynamics 32, 1107-1117. doi:10.1007/s00382-008-0439-x

Popa, I., Sidor, C. G., 2010. Romanian dendrochronological network - Rodendronet - 1 . conifers, Editura Silvică, ISBN 978-606-8020-11-2.

Popa, I., Kern, Z., Nagy, B., 2006. Frost ring: a biological indicator of widespread freezing days, and $1876 \mathrm{AD}$ as a case study from the Eastern Carpathians. Proceeding of the Romanian Academy seriesB, 8/1: 55-61.

Primicia, I., Camarero, J. J., Janda, P., Čada, V., Morrissey, R. C., Trotsiuk, V., Bace, R., Teodosiu, M., Svoboda, M. 2015. Age, competition, disturbance and elevation effects on tree and stand growth response of primary Picea abies forest to climate. Forest Ecology and Management. 354, 77-86. doi:10.1016/j.foreco.2015.06.034

Reimer, P. J., Bard, E., Bayliss, A., Beck, J. W., Blackwell, P. G., Bronk Ramsey, C., Grootes, P. M., Guilderson, T. P., Haflidason, H., Hajdas, I., Hatte, C., Heaton, T. J., Hoffmann, D. L., Hogg, A. G., Hughen, K. A., Kaiser, K. F., Kromer, B., Manning, S. W., Niu, M., Reimer, R. W., Richards, D. A., Scott, E. M., Southon, J. R., Staff, R. A., Turney, C. S. M., van der Plicht, J., 2013. IntCal13 and Marine13 radiocarbon age calibration curves 0-50,000 years cal BP. Radiocarbon, 55(4), 1869-1887.

Rinn, F., 2005. TSAP reference manual. 110 p.

Rinyu L., Molnár M., Major I., Nagy T., Veres M., Kimák Á., Wacker, L., Synal, H.-A., 2013. Optimization of sealed tube graphitization method for environmental 14C studies using MICADAS. Nuclear Instruments and Methods in Physics Research Section B Beam Interactions with Materials and Atoms 294, 270-275.

Savva, Y., Oleksyn, J., Reich, P. B., Tjoelker, M. G., Vaganov, E. A., Modrzynski, J., 2006. Interannual growth response of Norway spruce to climate along an altitudinal gradient in the Tatra Mountains, Poland. Trees 20, 735-746.

Selsing, L., 1998. Subfossils of Scots pine (Pinus sylvestris L.) from the mountain area of South Norway as the basis for a long tree-ring chronology, Norsk Geografisk Tidsskrift 52/2, 89-103. doi: 10.1080/00291959808552388

Sidor, C. G., Popa, I., Vlad, R., Cherubini, P., 2015. Different tree-ring responses of Norway spruce to air temperature across an altitudinal gradient in the Eastern Carpathians (Romania). Trees 29, 985-997.

Speer, J. H. 2010. Fundamentals of tree-ring research. University of Arizona Press.

Stuiver, M., Polach, H. A., 1977. Reporting of C-14 data - Discussion. Radiocarbon 19, 355363.

Timis, V., Popa, I., 2010. Spatial variability of dendrochronological series from Rodna Mountains (Eastern Carpathians - Romania). Proceeding of Academia Romana, Series B 12, 167-170. 